\title{
Challenges in Nuclear Posture and Deterrence from Pakistan's Perspective
}

\author{
Author: Sultan, Adil
}

To cite this article: Sultan, A. (2021). Challenges in Nuclear Posture and Deterrence from Pakistan's Perspective. National Security Journal. Published 24 December 2021. doi: $10.36878 /$ nsj20211224.05

To link to this article: https://doi.org/10.36878/nsj20211224.05

View CrossRef data: https://search.crossref.org/?q=10.36878\%2Fnsj20211224.05 


\title{
CHALLENGES IN NUCLEAR POSTURE AND DETERRENCE FROM PAKISTAN'S PERSPECTIVE
}

\begin{abstract}
Adil Sultan ${ }^{1}$
India and Pakistan are engaged in a nuclear arms competition with new technologies and systems that have a direct bearing on their respective doctrines and nuclear postures. The statements by senior Indian leadership over the past few years throw into question the viability of India's no-first-use posture and have placed further stress on the deterrence relationship between these two regional adversaries. India's efforts to explore space for a limited war in a nuclearised environment have encouraged Pakistan to introduce remedial measures in the form of shortrange ballistic missiles. These are part of its full spectrum deterrence, which aims to deter an entire spectrum of conventional and nuclear threats. India's work to operationalise its second-strike capability, acquisition of ballistic missile defences and development of hypersonic weapons could undermine regional strategic stability. These efforts require countermeasures on the part of Pakistan to ensure deterrence stability between the two nuclear armed neighbours.
\end{abstract}

Key Words: cold start strategy, pro-active operations strategy, full spectrum deterrence, no first use, South Asia

\section{Introduction}

China, India and Pakistan are building military nuclear capabilities and developing new doctrines that are generally perceived to be part of a triangular competition. ${ }^{1}$ However, the scope and trajectories of their military developments suggest that even if these three are embroiled in an arms race, they seem to be moving on different tracks. China

$1 \quad$ Adil Sultan is the Dean and Head of Department at Air University in Pakistan. 
is building capabilities to counter the US threat. In turn, India reacts to China by making qualitative and quantitative improvements to its own nuclear arsenal, which forces Pakistan to take corrective measures to ensure the credibility of its deterrence posture against India. This action-reaction phenomenon may give a perception of triggering a triadic nuclear competition in South Asia. Yet it could best be described as a set of two asymmetric dyads between China and India, and between India and Pakistan.

There are several explanations behind this. India perceives China to be its principal adversary but continues to maintain Pakistan-specific conventional and nuclear postures. As India grows in size in terms of conventional and nuclear capabilities, in the process reorienting its security interests, it may decide to 'decouple' its military doctrines to deal with China and Pakistan differently. ${ }^{2}$ This could result in a more aggressive posture against Pakistan to assert its dominance over relatively smaller regional powers, while ensuring credible deterrence against China. Maintaining two different sets of doctrines and planning to fight a 'two-front' war would have its own inherent problems of operationalisation. ${ }^{3}$ This is due to the fact that no nuclear state has the capacity to maintain two different sets of nuclear postures against two different nuclear powers. Thus, while Indian discourse may argue that both China and Pakistan are linked, in reality India deals with the two differently, as was witnessed during its recent border skirmishes with both China and Pakistan. Notwithstanding the discourse in India, the reality is that neither China nor Pakistan will fight for each other against India. Both have their own security interests and military doctrines. To better understand these shifting dynamics, this essay will address prevailing uncertainties and misperceptions about nuclear use policies of India and Pakistan to analyse South Asian nuclear developments that keep the region in a state of flux between stability and instability.

\section{The Controversy Surrounding India's NFU Posture}

India's draft nuclear doctrine of 1999 included a commitment that it 'will not be the first to initiate nuclear strike.. ${ }^{4}$ However, this pledge became conditional in the 2003 nuclear doctrine released by the Indian government, which stated that India will retain the right to use nuclear weapons 'in response to the use of chemical or biological weapons against India or the Indian forces anywhere. ${ }^{5}$ While this latter doctrine may not have been released as an official document, Indian officials continue to cite it and no one has ever contradicted it. Thus, with this caveat in its 2003 nuclear doctrine, India effectively nullified its no-first-use (NFU) commitment, in spite of the fact that it officially continues to assert that there is no change in India's NFU stance. ${ }^{6}$

Further, commentary by senior members of India's Nuclear Command Authority has also made this NFU pledge less credible. Former National Security Advisor, Shiv Shankar Menon, wrote in his book that: '[T]here is potential grey area as to when India would use nuclear weapons first against another NWS [nuclear weapon state]. Circumstances are conceivable in which India might find it useful to strike first, for instance, 
against an NWS that had declared it would certainly use its weapons, and if India were certain that adversary's launch was imminent.7 The possibility of a first use-or a first strike in response to the threat of nuclear weapon use-particularly when India lacks the requisite intelligence, reconnaissance and early warning means to verifiably reach such a conclusion, is not only escalatory but negates the basic principle of a NFU pledge.

Nevertheless, India is seeking to rectify some of these gaps by investing in its intelligence, information, surveillance and reconnaissance (I2SR) capabilities. It has a number of indigenously launched military satellites and has also demonstrated the capability to neutralise adversaries' satellites by testing an anti-satellite weapon. ${ }^{8}$ More recently, India and the United States have concluded foundational agreements as part of their overarching strategic partnership, which also includes the Basic Exchange and Cooperation Agreement (BECA). ${ }^{9}$ This collaboration will give India access to sensitive geospatial information from US space-based assets, as well as other navigational equipment used on US aerial platforms, such as drones and reconnaissance aircraft.

However, rather than bolstering NFU, India's improved situational awareness may incentivise Indian military planners to launch pre-emptive counterforce strikes against Pakistan. Alternatively, it may enable them to use this capability, along with precision weapons, to deter Pakistan from early deployment of its short-range ballistic missiles (SRBMs) in a future military crisis. This could potentially open the space for the Indian military to launch its pro-active operations strategy, which evolved from its cold start strategy. ${ }^{10}$ These strategies had been previously considered difficult to execute due to the threat of use of SRBMs by Pakistan against India's integrated battle groups. ${ }^{11}$

\section{A Limited Nuclear War Versus a Cold War Model}

To better understand the current debate over limited nuclear war, it is instructive to begin by discussing the Cold War model. Escalate to de-escalate strategy was used by the United States during the Cold War and included the possibility of engaging in a limited nuclear war. Russia's 2020 'Basic Principles on Nuclear Deterrence' has also been interpreted by some as part of an escalate to de-escalate strategy. ${ }^{12}$ While the major nuclear powers can afford to plan for nuclear wars-notwithstanding the disastrous consequences for the rest of the international community-this may not hold true for smaller nuclear powers. This is particularly the case with Pakistan, which continues to strengthen its nuclear deterrence with the primary objective of preventing an entire spectrum of war with India.

To this end, Pakistan introduced its SRBMs as part of its posture of full spectrum deterrence, which aims at deterring the complete spectrum of threats and includes options to deter limited to all-out war between the two nuclear adversaries. ${ }^{13}$ In addition to nuclear options, Pakistan has also developed adequate conventional responses that help 
to keep the nuclear threshold reasonably high. Pakistan's deliberate ambiguity regarding its nuclear threshold has helped achieve this objective but has been misinterpreted by some as a nuclear warfighting strategy. ${ }^{14}$

Pakistan's nuclear strategy is unlike the United States' and North Atlantic Treaty Organization's strategy of limited nuclear options that were practiced during the Cold War. This is because the United States and the former Union of Soviet Socialist Republics (USSR) were engaged in developing nuclear warfighting strategies premised upon a belief that limited nuclear wars could be fought without completely annihilating the other side. Unlike the case of proxies used by the USSR and the United States during the Cold War, any use of nuclear weapon by Pakistan or India will have direct bearing for both the countries, and therefore remains a major consideration by the leadership on both the sides.

To reduce the possibility of early nuclear use, Pakistan maintains adequate conventional responses to counter India's offensive military strategy of pro-active operations, and the relatively new strategy of surgical strikes. These were on display during the 2019 crisis in Pulwama and Balakot, when Pakistan retaliated with a matching response and did not resort to the use or even the threat to use nuclear weapons. ${ }^{15}$

During this crisis, Pakistan effectively used its Air Force to launch counter aerial strikes in response to the Indian aggression and managed to shoot down two aircraft of India's Air Force. ${ }^{16}$ These events surrounding Pulwama and Balakot may have enhanced Pakistan's confidence in its application of conventional deterrence. However, in light of the longstanding nature of such threats from India, it is unlikely that Pakistan would ever rule out the possibility of nuclear weapons use under a pre-defined set of conditions that are unlikely to be made public.

\section{Impact of Technology on Nuclear Postures and Deterrence}

India and Pakistan are modernising their military capabilities in line with their national security priorities. If both adversaries possess a credible second-strike capability, this is generally viewed as a stabilising factor. This is due to the fact that a lack of second-strike capability on the part of one country could encourage the other in possession of this capability to contemplate pre-emptive strikes. These concerns become more prominent in South Asia, in view of the statements emerging from within India about the possibility of a first strike against Pakistan. ${ }^{17}$

\section{SSBNS}

India has operationalised its Arihant-class nuclear-powered ballistic missile submarines (SSBNs). ${ }^{18}$ India's Arihant-class SSBNs can reportedly carry strategic weapons with ranges between $750-1,000 \mathrm{~km}$, which are not adequate to cover major Pakistani 
cities and much less Chinese targets. ${ }^{19}$ In the absence of a robust command and control system for authorising the use of nuclear weapons-as India is still in the process of developing a credible second-strike capability-there would always be a risk of miscommunication leading to an unauthorised use of nuclear weapons.

One illustration of this was India's deployment of a nuclear submarine during the 2019 Pulwama and Balakot crisis, which was likely not authorised by its political leadership. ${ }^{20}$ This deployment during a crisis could have led to miscommunication that India was preparing for a pre-emptive first strike. Likewise, if Pakistan's Navy had not demonstrated restraint and instead destroyed the SSBN, it could have escalated the crisis with serious consequences for regional stability.

\section{MIRVs, ICBMs and Tactical Missiles}

India is also developing multiple independently targetable re-entry vehicles (MIRVs) and intercontinental ballistic missiles (ICBMs) that would significantly improve the penetration and range of India's ballistic missiles. ${ }^{21}$ The reported development of Surya ICBM missile with a range from 12,000-16,000 kilometres would significantly enhance India's reach beyond China to other continents. ${ }^{22}$

In addition to these longer range missiles, India has also developed shorter range tactical missiles, such as the Prahaar that is reportedly capable of 'carrying different warheads. ${ }^{23}$ While reports have not clarified whether these warheads would be both nuclear and conventional, such flexibility in platforms could encourage India to contemplate limited nuclear warfighting, in the event that Pakistan decides to use its SRBMs against India's pro-active operations strategy.

\section{Missile Defences}

Ballistic missile defence (BMD) systems are unlikely to be effective in South Asia due to the close proximity of the two nuclear adversaries and the short flight time of missiles, making it difficult for any defensive system to detect and intercept the incoming missiles. Nevertheless, BMD could provide a false sense of security and an incentive for Indian decision makers to launch a pre-emptive counterforce strike against Pakistan.

Moreover, in addition to India's indigenous multi-layered Prithvi Air Defence (PAD) and Advanced Air Defence (AAD) systems, it is in the process of acquiring an anti-missile system that includes Russian supplied S-400s surface-to-air missiles. ${ }^{24}$ It has also demonstrated its capability to shoot down space-based satellites and more recently has tested hypersonic weapons. ${ }^{25}$ In response to these various developments, Pakistan could resort to the early use of nuclear weapons to avoid a 'use or lose' dilemma. Pakistan could also decide to further increase the number and mobility of its nuclear arsenal to ensure that it would retain a sufficient capability to cause unacceptable damage to its adversary after absorbing a first strike. 


\section{Hypersonic Weapons}

Acquisition of hypersonic weapons by India is likely to lead to further instability. Hypersonic weapons are more suitable for employment against mobile ground-based missile systems, such as Pakistan's SRBMs. Within Pakistan, these systems are seen as a major factor in preventing India from launching its limited warfighting strategy of pro-active operations. Since India's hypersonic weapons are likely to be equipped with conventional warheads, India may be hoping that a conventional hypersonic strike against Pakistan's SRBMs may make it difficult for the latter to respond with nuclear weapons.

From an Indian perspective, this could open the aperture for a limited conventional military conflict. The threat of a pre-emptive counterforce strike against its SRBMs is likely to push Pakistan to take steps that may include putting the missiles on a higher alert status. Much like with BMD, Pakistan would also be compelled to increase its numbers and mobility of its nuclear arsenal. When combined with other countermeasures, these shifts could adversely affect strategic stability in the region.

\section{Conclusion}

South Asia remains one of the most vulnerable regions in the world, in which the possibility of a breakdown of nuclear deterrence cannot be ruled out. Due to the nature of the rivalry between India and Pakistan and their long history of mutual distrust, it would be unrealistic to expect that the two countries would be able to resolve their disputes in the near future. Furthermore, involvement of extra-regional powers and their ongoing efforts to help India improve its conventional as well as nuclear capabilities continue to compound the regional security matrix and have made the region highly unstable.

The ambiguity surrounding India's NFU posture, its ongoing military developments that include the introduction of limited warfighting doctrines in a nuclearised environment, development of a second-strike capability, acquisition of missile defence systems and the hypersonic weapons, are together seen by Pakistan as destabilising for strategic stability in the region. Notwithstanding the commonly held perception that India's military modernisation is aimed at China, most of the ongoing developments impinge upon Pakistan's security interests, forcing the latter to take corrective measures that in turn could trigger a new arms race between the two nuclear neighbours.

India would like to be competetive with China in the region, but it is unlikely that it would want to confront China militarily in the foreseeable future, as was the case during the 2020 border skirmishes in the Galwan Valley. ${ }^{26}$ Thus, in reviewing the nature of competition in the region, if there is a potential for a conflict or a deterrence breakdown, it will most likely occur in the India-Pakistan dyad and not necessarily in the China-India dyad. The latter two countries do not want to entangle themselves in a serious bilateral military conflict. Therefore, the most likely possibility of deterrence breakdown remains between India and Pakistan. 
1 For a different perspective, see Einhorn, Robert and Sidhu, Waheguru Pal Singh, 'The strategic chain: Linking, Pakistan, India, China, and the United States', Brookings, 2 Mar. 2017, <https://www. brookings.edu/research/the-strategic-chain-linking-pakistan-india-china-and-the-united-states $>$.

2 Narang, Vipin, 'Beyond the Nuclear Threshold: Causes and Consequences of First Use', Speech at Carnegie International Nuclear Policy Conference, Washington, D.C., 20-21 Mar. 2017, <https://youtu. be/ChdTSSRIXB8>.

3 Sareen, Sushant, 'Two Front War', Observer Research Foundation, 24 Jun. 2020, <https://www. orfonline.org/research/two-front-war-68382>.

4 Arms Control Association, 'India's Draft Nuclear Doctrine', <https://www.armscontrol.org/act/199907/indias-draft-nuclear-doctrine>, accessed on 13 Oct. 2021.

5 Ministry of External Affairs, 'The Cabinet Committee on Security Reviews perationalization [sic.] of India's Nuclear Doctrine', Republic of India, 4 Jan. 2003, <https://mea.gov.in/press-releases. $\mathrm{htm}$ ?dtl/20131/The_Cabinet_Committee_on_Security_Reviews_perationalization_of_Indias_Nuclear_Doctrine+Report + of + National+Security + Advisory+Board+on+Indian+Nuclear+Doctrine $\overline{>}$.

6 Saalman, Lora, 'India's no-first-use dilemma: Strategic consistency or ambiguity towards China and Pakistan', Stockholm International Peace Research Institute, 2 Dec. 2020, <https://www.sipri.org/ commentary/blog/2020/indias-no-first-use-dilemma-strategic-consistency-or-ambiguity-towards-china-and-pakistan>.

7 Menon, Shivshankar, Choices: Inside the Making of India's Foreign Policy (Washington, D.C.: Brookings Institution Press, 2016), 110.

8 Davenport, Kelsey, 'Indian ASAT Test Raises Space Risks', Arms Control Today, May 2019, $<$ https://www.armscontrol.org/act/2019-05/news/indian-asat-test-raises-space-risks $>$.

9 Roy, Shubhajit, 'Explained: BECA, and the importance of 3 foundational pacts of India-US defence cooperation', The Indian Express, 3 Nov. 2020, <https://indianexpress.com/article/explained/beca-indiaus-trade-agreements-rajnath-singh-mike-pompeo-6906637>.

10 Sultan, Adil, 'South Asian Stability-Instability Paradox: Another Perspective', IPRI Journal, vol 14, no. 1, Winter 2014, 21-37.

11 Dutta, Amrita Nayak, 'Indian Army's new Integrated Battle Groups to be introduced in early 2020”, The Print, 26 Nov. 2019, <https://theprint.in/defence/indian-armys-new-integrated-battle-groups-to-be-introduced-in-early-2020/326253>.

12 Ross, Jay, 'Time to Terminate Escalate to De-escalate - It's Escalation Control', War on the Rocks, 24 Apr. 2018, <https://warontherocks.com/2018/04/time-to-terminate-escalate-to-de-escalateits-escalation-control>.

13 Sultan, Adil, 'Missile Developments in South Asia: a perspective from Pakistan', International Institute for Strategic Studies, 6 May 2021, <https://www.iiss.org/blogs/research-paper/2021/05/missile-developments-south-asia>.

14 Ibid.

15 In February 2019 India launched an aerial surgical strike across the Line of Control against alleged militant hideouts. In response, Pakistan retaliated with a 'tit-for-tat' kind of an aerial surgical strike to signal its resolve. The crisis eventually dissipated as both sides restrained from further escalation. Yusuf, Moeed W., 'The Pulwama Crisis: Flirting With War in a Nuclear Environment', Arms Control Today, May 2019, <https://www.armscontrol.org/act/2019-05/features/pulwama-crisis-flirting-war-nuclear-environment>.

16 Dawn, '2 Indian aircraft violating Pakistani airspace shot down; pilot captured', 27 Feb. 2019, $<$ https://www.dawn.com/news/1466347/2-indian-aircraft-violating-pakistani-airspace-shot-down-pilot-arrested $>$.

17 Stowe-Thurston, Abigail, ‘Added Ambiguity Over India's No First Use Policy is a Cause for Concern', Centre for Arms Control and Nonproliferation, 22 Aug. 2019, <https://armscontrolcenter.org/whyindia-and-pakistan-should-both-have-no-first-use-policies>.

18 Nuclear Threat Initiative, 'India Submarine Capabilities', 18 Feb. 2021, <https://www.nti.org/analysis/articles/india-submarine-capabilities>.

19 Joshi, Yogesh, 'Angles and Dangles: Arihant and the Dilemma of India's Undersea Nuclear Weapons', War on the Rocks, 14 Jan. 2019, <https://warontherocks.com/2019/01/angles-and-dangles-arihant-and-the-dilemma-of-indias-undersea-nuclear-weapons $>$. 
20 ANI, 'Navy says it deployed nuclear submarines, aircraft carrier during India-Pak tensions', Business Standard, 17 Mar. 2019, <https://www.business-standard.com/article/news-ani/navy-says-it-deployed-nuclear-submarines-aircraft-carrier-during-india-pak-tensions-119031700601_1.html>.

21 Bhatia, V.K.,'India Developing MIRVS', SP's Aviation, Oct. 2009, <http://www.sps-aviation.com/ story/?id=370>.

22 O'Donnel, Frank and Bollfrass, Alexander K., 'India is building nuclear submarines and ICBMs. That's a \$14 billion mistake', The Bulletin of the Atomic Scientists, 26 Feb. 2020, <https://thebulletin. org/2020/02/india-is-building-nuclear-submarines-and-icbms-thats-a-14-billion-mistake>.

23 Army Technology, 'Indian Army test launches Prahaar short-range ballistic missile', 21 Sep. 2018, $<$ https://www.army-technology.com/news/india-test-launches-prahaar-missile>; India Tests Prahar ATACMS-like Tactical Missile, Press Information Bureau, 21 Jul. 2011, <http://www.defense-aerospace. com/articles-view/release/3/127356/india-tests-prahar-atacms_like-tactical-missile.html>.

24 Gady, Franz-Stefan, 'Report: India's Homemade Anti-Ballistic Missile Shield Ready', The Diplomat, 8 Jan. 2020, <https://thediplomat.com/2020/01/report-indias-homemade-anti-ballistic-missile-shield-ready>.

25 Sutton, H., 'India Goes Hypersonic: New Missile Technology May Be Answer To China's Navy', Forbes, 8 Sep. 2020, <https://www.forbes.com/sites/hisutton/2020/09/08/india-goes-hypersonic-new-missile-technology-may-be-answer-to-chinas-navy/?sh=26ad5e26d937>.

26 Both India and China were engaged in a military stand-off along the Line of Actual Control, which included minor scuffles. Eventually both sides agreed to tone down the rhetoric and a major crisis was averted. The Indian Express, 'Galwan Valley: A year after the violent clash', 14 Jun. 2021, $<$ https://indianexpress.com/article/india/galwan-valley-clash-timeline-india-china-disengagement-7358554>. 